\title{
Tissue-specific evaluation of suitable reference genes for RT- qPCR in the pond snail, Lymnaea stagnalis
}

\author{
Alexander P Young ${ }^{\text {Corresp., }}{ }^{1}$, Carmen F Landry ${ }^{1}$, Daniel J Jackson ${ }^{2}$, Russell C Wyeth ${ }^{1}$ \\ 1 Department of Biology, St. Francis Xavier University, Antigonish, NS, Canada \\ 2 Department of Geobiology, Georg-August Universität Göttingen, Göttingen, Germany \\ Corresponding Author: Alexander P Young \\ Email address: ayoung@stfx.ca
}

Reverse transcription quantitative PCR (RT-qPCR) is a robust technique for the quantification and comparison of gene expression. To obtain reliable results with this method, one or more reference genes must be employed to normalize expression measurements among treatments or tissue samples. Candidate reference genes must be validated to ensure that they are stable prior to use in qPCR experiments. The pond snail (Lymnaea stagnalis) is a common research organism, particularly in the areas of learning and memory, and is an emerging model for the study of biological asymmetry, biomineralization, and evolution and development. However, no systematic assessment of qPCR reference genes has been performed in this animal. Therefore, the aim of our research was to identify stable reference genes to normalize gene expression data from several commonly studied tissues in L. stagnalis as well as across the entire body. We evaluated a panel of seven reference genes across six different tissues in $L$. stagnalis with RT-qPCR. The genes included: elongation factor 1-alpha (EF1 $\alpha)$, glyceraldehyde-3phosphate dehydrogenase (GAPDH), beta-actin (ACTB), beta-tubulin (TUBB), ubiquitin $(U B I)$, prenylated rab acceptor protein 1 (Rapac1), and a voltage gated potassium channel (VGKC). These genes exhibited a wide range of expression levels among tissues. The tissue-specific stability of each of the genes was consistent when measured by the standard stability assessment algorithms: geNorm, NormFinder, BestKeeper and RefFinder. Our data indicate that the most stable reference genes vary among the tissues that we examined (central nervous system, tentacles, lips, penis, foot, mantle). Our results were generally congruent with those obtained from similar studies in other molluscs. Given that a minimum of two reference genes are recommended for data normalization, we provide suggestions for strong pairs of reference genes for single- and multi-tissue analyses of RTqPCR data in Lymnaea stagnalis. 
1 Tissue-specific evaluation of suitable reference genes for RT-qPCR in the pond snail,

\section{$2 \quad$ Lymnaea stagnalis}

3

4 Alexander P. Young ${ }^{1}$, Carmen F. Landry ${ }^{1}$, Daniel J. Jackson ${ }^{2}$, Russell C. Wyeth ${ }^{1}$

$6{ }^{1}$ Department of Biology, St. Francis Xavier University, Antigonish, Nova Scotia, Canada

7 2Department of Geobiology, Georg-August University of Göttingen, Göttingen, Germany

8

9 Corresponding Author:

10 Alexander Young ${ }^{1}$

112320 Notre Dame Ave, Antigonish, B2G 1Z3, Canada

12 Email address: ayoung@stfx.ca

13

14 


\section{Abstract}

16 Reverse transcription quantitative PCR (RT-qPCR) is a robust technique for the quantification

17 and comparison of gene expression. To obtain reliable results with this method, one or more

18 reference genes must be employed to normalize expression measurements among treatments or

19 tissue samples. Candidate reference genes must be validated to ensure that they are stable prior to

20 use in qPCR experiments. The pond snail (Lymnaea stagnalis) is a common research organism,

21 particularly in the areas of learning and memory, and is an emerging model for the study of

22 biological asymmetry, biomineralization, and evolution and development. However, no

23 systematic assessment of qPCR reference genes has been performed in this animal. Therefore,

24 the aim of our research was to identify stable reference genes to normalize gene expression data

25 from several commonly studied tissues in L. stagnalis as well as across the entire body. We

26 evaluated a panel of seven reference genes across six different tissues in L. stagnalis with RT-

27 qPCR. The genes included: elongation factor 1-alpha (EF1 1 ), glyceraldehyde-3-phosphate

28 dehydrogenase (GAPDH), beta-actin (ACTB), beta-tubulin (TUBB), ubiquitin (UBI), prenylated

29 rab acceptor protein 1 (Rapacl), and a voltage gated potassium channel ( $V G K C)$. These genes

30 exhibited a wide range of expression levels among tissues. The tissue-specific stability of each of

31 the genes was consistent when measured by the standard stability assessment algorithms:

32 geNorm, NormFinder, BestKeeper and RefFinder. Our data indicate that the most stable

33 reference genes vary among the tissues that we examined (central nervous system, tentacles, lips,

34 penis, foot, mantle). Our results were generally congruent with those obtained from similar

35 studies in other molluscs. Given that a minimum of two reference genes are recommended for

36 data normalization, we provide suggestions for strong pairs of reference genes for single- and

37 multi-tissue analyses of RT-qPCR data in Lymnaea stagnalis. 


\section{Background}

Lymnaea stagnalis is a freshwater snail with an extensive history of proximate mechanism research. Previous studies have primarily focused on its neurobiology, as well as its endocrinology, immunology and shell morphology (Chase, 2002; Benjamin, 2008). The central nervous system (CNS) is relatively simple, with approximately 20,000 neurons, many of which are large and easily identifiable, making them amenable for studies of learning, memory, motor pattern generation, neuronal regeneration and synapse formation (Lukowiak; Elliott \& Susswein, 2002; Chase, 2002; Lukowiak et al., 2003; Getz et al., 2018). Parallel investigations into the neuroendocrine (Koene, 2010; Pirger et al., 2010) and immune (van der Knaap, Adema \& Sminia, 1993; Gust et al., 2013a) systems of L. stagnalis and other gastropods have improved our understanding of reproductive behaviour, immunity and toxicology of L. stagnalis. Additionally, L. stagnalis has been used as a research organism to study the molecular mechanisms that guide shell formation (Boer \& Witteveen, 1980; Ebanks, O’Donnell \& Grosell, 2010; Hohagen \& Jackson, 2013; Jackson, Herlitze \& Hohagen, 2016; Herlitze et al., 2018).

More recently, L. stagnalis has also been used to study the molecular basis of body asymmetry (Davison et al., 2016; Abe \& Kuroda, 2019).

A broad range of traditional techniques have been used in past studies, but modern molecular genetics have yet to be thoroughly incorporated into the study of L. stagnalis. Methods to study the genetics of $L$. stagnalis such as reverse transcription quantitative PCR (RT-qPCR), in situ hybridization, and transcriptomics (among others) have been established but have not yet been used extensively (Feng et al., 2009; Herlitze et al., 2018). The few studies using RT-qPCR have 
61 spanned several topics including chirality, learning, and memory (Sadamoto et al., 2010; Foster,

62 Lukowiak \& Henry, 2015; Davison et al., 2016; Korneev et al., 2018; Dong et al., 2018).

63 Additionally, a small number of studies have used in situ hybridization in this species, primarily

64 in sections and whole mounts of the CNS, as well as larvae (Dirks et al., 1989; Boer et al., 1992;

65 Croll \& Minnen, 1992; Sadamoto et al., 2004). Our goal here is to continue to build the

66 foundation for further molecular genetics studies in L. stagnalis via validation of candidate

67 reference genes for RT-qPCR.

69 RT-qPCR is a robust technique for the quantification of the mRNA for a specific transcript. It

70 can be used alongside in situ hybridization or other visualization techniques to establish patterns

71 of gene expression in animals. For such experiments, relative quantification against one or more

72 reference genes is the most common choice to compare gene expression across samples

73 (Schmittgen \& Livak, 2008; Ruijter et al., 2009). Historically, highly expressed cellular

74 maintenance genes have been haphazardly selected as reference genes for qPCR experiments in

75 many species because expression of such genes was thought to be inherently stable (Kozera \&

76 Rapacz, 2013). However, many of these genes have been shown to have unstable expression in

77 several species of plants and animals, highlighting the importance of species-specific validation

78 prior to use (Dheda et al., 2004; Barber et al., 2005; Jonge et al., 2007; Tong et al., 2009; Eissa et

79 al., 2016). Therefore, validation that candidate reference genes have stable expression is critical

80 for the acquisition of accurate qPCR data and the experimental approaches that incorporate this

81 technique.

82 
83 To our knowledge, the only previous example of reference gene validation in L. stagnalis is for

84 EF1 $\alpha$ in the CNS (Foster, Lukowiak \& Henry, 2015). Other experiments have used reference

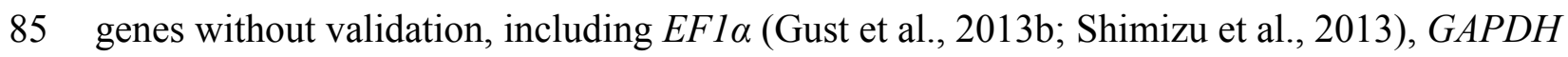

86 (Aleksic \& Feng, 2012), ACTB (Senatore \& Spafford, 2012; Hatakeyama et al., 2013; Carter et

87 al., 2015) and TUBB (Bavan et al., 2012; Korneev et al., 2013; Gust et al., 2013b; Flynn et al.,

88 2014; Carter et al., 2015; Benatti et al., 2017). To establish a more rigorous foundation for future

89 research using RT-qPCR, we present an analysis of seven candidate reference genes across six

90 tissues of interest (tentacles, lips, foot, penis, mantle, and CNS) in L. stagnalis. We also provide

91 a combined analysis with data from all tissues to demonstrate which genes are likely to be most

92 stably expressed in whole-body preparations of $L$. stagnalis.

93

94 We investigated the stability of Lst-EF1 $\alpha$, Lst-GAPDH, Lst-ACTB, Lst-TUBB and Lst-ubiquitin

$95(U B I)$ as they are commonly employed reference genes. Messenger RNA transcripts encoding

96 the prenylated rab acceptor protein 1 (Rapacl) and a voltage gated potassium channel ( $V G K C)$

97 were also assessed as analogs of these genes have recently been found to be stable in the

98 terrestrial gastropod Cepaea nemoralis (Affenzeller, Cerveau \& Jackson, 2018).

\section{Methods}

\section{Care of Snails}

102 Animal use was consistent with the Canadian Council for Animal Care guidelines. A colony of

103 Lymnaea stagnalis was bred and maintained in the animal care facility at StFX. The animals

104 were exposed to a photoperiod matched to natural daylight patterns in Antigonish, Nova Scotia. 
105 The water in the animals' tanks was changed three times per week. The animals were fed fish

106 food and romaine lettuce ad libitum plus sinking protein pellets once per week.

107

\section{Total RNA Extraction}

109 Total RNA was collected from each L. stagnalis tissue of interest. To prepare for RNA isolation,

110 animals were anesthetized in 0.125\% 1-phenoxy-2-propanol dissolved in Lymnaea saline for up

111 to 30 minutes (Wyeth et al., 2009). The animals were dissected to isolate the six tissues of

112 interest: CNS, tentacles, lips, penis, foot and mantle. The tissues of each type from two animals

113 were combined for each replicate to ensure adequate yields of RNA from each tissue, three

114 replicates were produced with this method. Tissues were flash frozen in liquid nitrogen, shredded

115 with razor blades and added to $500 \mu \mathrm{L}$ of TRIzol reagent (ThermoFisher, Waltham, MA). Tissue

116 solutions were thoroughly homogenized with a PowerGen 125 tissue homogenizer

117 (ThermoFisher, Waltham, MA). Total RNA was extracted from the homogenized tissue via

118 addition of 0.5 volumes of a $24: 1$ solution of chloroform and isoamyl alcohol. The aqueous layer

119 was separated, and RNA was precipitated with isopropyl alcohol. RNA precipitate was

120 transferred to the spin column of the E.Z.N.A. ${ }^{\circledR}$ Mollusc RNA Kit (Omega Bio-Tek, Norcross,

121 GA) where the RNA was washed and subjected to the on-column DNAse I treatment as per the

122 manufacturer's instructions. To confirm the effectiveness of the DNase I treatment, PCR was

123 performed with primer sets for Lst-tyrosine hydroxylase (forward: 5'-

124 CCCACGTGTATCGTCATCTTA-3'; reverse: 5'-ATCTTCTCCTCGCAAAACC-3') and Lst-

$125 E F 1 \alpha$ with $20 \mathrm{ng}$ of total RNA as a template as this reaction would not work in the absence of

126 genomic DNA (gDNA) contamination. Lst-tyrosine hydroxylase was chosen as one of the gDNA

127 contamination controls as it is frequently amplified by us in all of the tissues of interest as a part 
128 of a larger research project on neural development. No amplification was observed for either

129 gene in any of the RNA samples after 40 cycles, thus the RNA samples were judged to be free of 130 gDNA contamination.

131

132 Total RNA was quantified in a QuBit 3.0 (ThermoFisher, Waltham, MA). Yields of 50-200

$133 \mathrm{ng} / \mu \mathrm{L}$ dissolved in $30 \mu \mathrm{L}$ of molecular grade water were common for roughly $40 \mathrm{mg}$ of tissue

134 mass. A sample of total RNA was measured with a spectrophotometer to confirm a 260:280 ratio

135 of 1.8-2.0. Lastly, $5 \mu \mathrm{L}$ of each RNA sample was denatured in $5 \mu \mathrm{L}$ of $2 \mathrm{X}$ RNA Loading Dye

136 (New England Biolabs, Ipswich, MA) at $75^{\circ} \mathrm{C}$ for 10 minutes and then immediately placed on

137 ice. The RNA samples were loaded on a $1 \%$ agarose non-denaturing gel and run alongside a

138 single stranded RNA ladder (New England Biolabs) to verify that the 28S and 18S rRNA bands

139 were intact and the RNA samples were not degraded.

140

141 Reverse Transcription PCR

142 RT-PCR was performed with iScript Reverse Transcription Supermix for RT-qPCR (Bio-Rad

143 Laboratories, Hercules, CA) which contains a mixture of oligo(dT) primers and random

144 hexamers. For RT-PCR reactions, $500 \mathrm{ng}$ of RNA was added to $4 \mu \mathrm{L}$ of iScript Supermix and

145 topped up to $20 \mu \mathrm{L}$ with molecular grade water as recommended by the manufacturer. RT-PCR

146 took place in a Bio-Rad CFX Connect thermocycler (Bio-Rad Laboratories; Hercules, CA). The

147 RT-PCR program ran at $25^{\circ} \mathrm{C}$ for 5 minutes, $46^{\circ} \mathrm{C}$ for 20 minutes and $95^{\circ} \mathrm{C}$ for 1 minute.

148

149 Design, validation and optimization of primers for quantitative PCR 
150 Candidate primers intended for qPCR were designed with CLC Main Workbench software

151 (Qiagen, Hilden, DE). Primers were designed to have a length of 19-23 nucleotides, a melting

152 temperature between $55-62^{\circ} \mathrm{C}$, a GC content between $40-60 \%$ and produce a product no more

153 than $200 \mathrm{bp}$ long. Additionally, the GC content of each primer was kept within $10 \%$ of its

154 counterpart, and the melting temperature of each was kept within $3^{\circ} \mathrm{C}$ of its counterpart.

155 Two to six sets of primers were designed for each gene so that optimal primers could be selected

156 for the qPCR reactions. The primers were tested on combined cDNA samples to minimize tissue-

157 specific bias. Melt curves were performed to verify that one product was amplified. If the

158 primers produced a single product, then $5 \mu \mathrm{L}$ of the PCR reactions were run on a $2 \%(\mathrm{w} / \mathrm{v})$

159 agarose gel at 60 volts for roughly 30 minutes alongside a 50 bp DNA Ladder (New England

160 BioLabs). The agarose gels were analyzed with a Bio-Rad ChemiDoc (Bio-Rad Laboratories) to

161 visualize the size of the product. Ultimately, one set of primers was selected for each candidate

162 reference gene based on the quality of the PCR product. The primers for each candidate

163 reference gene are listed in Table 1.

164

165 After the optimal primer sets were selected based on reaction specificity, primer efficiencies

166 were calculated for each primer set. Primer efficiency curves were generated from RT-qPCR

167 reactions on serial dilutions of RNA. The parent reaction contained $100 \mathrm{ng}$ total RNA and four

168 1:5 dilutions were performed to generate five Cq values.

169

170 Quantitative PCR

171 The Minimum Information for Publication of Quantitative Real-Time PCR Experiments (MIQE)

172 guidelines were followed throughout the collection of qPCR data (Bustin et al., 2009). 
173 Amplification of all genes was detected with SyBR Green dye which generates fluorescence

174 based on the synthesis of double-stranded DNA. The reactions contained $2 \mu \mathrm{L}$ of cDNA with 10

$175 \mu \mathrm{L}$ of Bio-Rad SsoAdvanced Universal SyBR Mix, $600 \mathrm{nM}$ forward and reverse primer

176 concentration, and topped to $20 \mu \mathrm{L}$ with $\mathrm{DEPC} \mathrm{H}_{2} \mathrm{O}$. Each replicate of $L$. stagnalis tissue was

177 subjected to qPCR reactions in triplicate. The qPCR reactions took place in a Bio-Rad CFX

178 Connect thermocycler running a custom program. The custom qPCR program consisted of $95^{\circ} \mathrm{C}$

179 for $30 \mathrm{~s} ; 40$ cycles of $95^{\circ} \mathrm{C}$ for $15 \mathrm{~s}, 55^{\circ} \mathrm{C}$ for $30 \mathrm{~s}$. The plate was read by the machine to measure

180 fluorescence at the end of each cycle.

181

\section{Data analysis}

183 The expression stability of each gene was assessed with four computational algorithms: geNorm

184 (Vandesompele et al., 2002), NormFinder (Andersen, Jensen \& Ørntoft, 2004), BestKeeper

185 (Pfaffl et al., 2004), and RefFinder (Xie et al., 2012). GeNorm ranks candidates by their

186 expression stability (M) values that are assigned following pair-wise variation measurements

187 among genes. Genes with $\mathrm{M}<1.5$ are considered to be stable. The NormFinder algorithm

188 compares intra-group variation (i.e. mRNA levels of one gene within the tissue of interest) to

189 inter-group variation (i.e. mRNA levels of other genes in the same tissues) and assigns genes a

190 stability value based on variation among Cq values. BestKeeper builds a stability index based on

191 repeated pair-wise correlation analyses between every reference gene and judges reference gene

192 stability based on the standard deviation (SD) from the index, genes that have a smaller SD will

193 be ranked more highly by BestKeeper. Finally, RefFinder was used to combine the ranked results

194 from each algorithm and assign each gene an overall rank.

195 
196 Data analyses were performed to compare the stability of among candidate reference genes in

197 each tissue of interest. Following the tissue-specific analyses, we also combined all data for

198 analysis together to simulate the conditions of a whole-body analysis. This approach allowed for

199 the identification of which genes are most stable in each tissue of interest and provided evidence

200 for which genes would be the strongest reference genes in an RT-qPCR experiment that used

201 RNA from a whole L. stagnalis body. Given that a minimum of two reference genes are typically

202 recommended for proper RT-qPCR data normalization, the recommended reference genes are

203 generally expressed in terms of pairs.

204

205 Results

206 Primer specificity and efficiency

207 Primers for all candidate reference genes were evaluated to ensure that they could produce

208 consistent results and not amplify off-target products or generate primer dimers. Following

209 amplification, each primer pair produced amplicons that yielded single bands at the correct size

210 after electrophoresis in 2\% agarose gels (Figure 1). Additionally, no amplification was observed

211 in controls that lacked reverse transcriptase in the RT-PCR or lacked cDNA template or primers

212 in qPCR. Thus, primer pairs specifically amplified a single cDNA target. Based on the standard

213 curves, primer set efficiencies ranged from 90\% (GAPDH and Rapacl) to $106 \%$ (ACTB) with

214 correlation coefficients $\left(\mathrm{R}^{2}\right)$ of $>0.980$ (Table 1$)$.

215

216 Insert Table 1 here

217

218 Tissue-specific expression profiles and stability of reference genes 
219 The candidate reference genes showed a variety of expression levels across individual tissues

220 (Figure 2). Lst-UBI produced the smallest mean Cq values and displayed the smallest $\mathrm{Cq}$ ranges

221 for most tissues (Table 2). Conversely, Lst-VGKC mRNA was the least abundant in every tissue

222 and displayed large $\mathrm{Cq}$ ranges.

223

224 The algorithms used to measure the stability of each candidate reference gene were highly 225 congruent in their tissue-specific rankings. Therefore, only the results from the RefFinder

226 analysis (which combines the rankings from the other three algorithms) are presented in Figure 3

227 (results for other algorithms reported in Figures S1, S2, S3). Lst-GAPDH and Lst-EF1 $\alpha$ were the 228 most stable candidate reference genes in the CNS and penis. Lst-UBI and Lst-GAPDH were the 229 most stable in the tentacles, Lst-GAPDH and Lst-Rapacl were the most stable in the lips, Lst$230 U B I$ and $L s t-A C T B$ were the most stable in the foot, and $L s t-U B I$ and $L s t-V G K C$ were the most 231 stable in the mantle. Overall, identification of the most reliable candidate reference gene was 232 tissue dependent. However, according to geNorm, all genes except for Lst-ACTB and Lst-TUBB 233 were acceptable as a reference genes for all tissues as they met the minimum stability threshold 234 of $\mathrm{M}<1.50$ for heterogeneous tissue samples.

236 Insert Table 2 here

237

238 Expression levels and stability of reference genes in a combined tissue analysis

239 To assess which candidate reference genes could be the most stable in whole-body preparations

240 of L. stagnalis, the data from all tissues was combined and analyzed together with geNorm,

241 NormFinder, BestKeeper, and RefFinder. The candidate reference genes spanned a wide range of 
242 expression levels when data from all tissue types was combined. Based on the Cq values, Lst-

$243 U B I$ was the most highly expressed gene (mean Cq $16.62 \pm 0.09$ ) and had the smallest overall Cq

244 range whereas $L s t-V G K C$ was the least expressed gene and had the highest biological variability

245 as measured by the standard error of the mean (mean Cq $29.87 \pm 0.19$; Table 2). All four

246 algorithms used to assess expression stability were highly congruent in their ranking of candidate

247 reference genes in the combined analysis (Figure 4). GeNorm, NormFinder, and RefFinder rated

$248 L s t-G A P D H$ and $L s t-E F l \alpha$ as the top two most stable reference genes. BestKeeper ranked Lst-

$249 U B I$ as the most stable with Lst-EFI $\alpha$ and $L s t-G A P D H$ as the second and third most stable,

250 respectively.

251

252 Discussion

253 We employed several established algorithms to analyze mRNA abundance data and identify

254 stably expressed genes that are suitable as reference genes for RT-qPCR in L. stagnalis. We

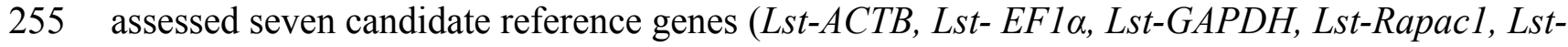

$256 T U B B, L s t-U B I$, and Lst-VGKC) in six tissues of interest (CNS, tentacles, lips, penis, foot, and

257 mantle) and provided a separate analysis of all tissues combined. There were variable patterns of

258 expression stability among the genes in the different tissues, but the tissue-specific rankings

259 produced by the different algorithms were highly congruent. Lst-GAPDH and Lst-EFla were the

260 most suitable pair of reference genes in the CNS and penis. However, Lst-UBI also was one of

261 the two most stable genes the tentacles, foot, and mantle when paired with Lst-GAPDH, Lst-

$262 A C T B$, and $L s t-V G K C$, respectively. Finally, $L s t-G A P D H$ and $L s t$-Rapacl were the most stable in

263 the lips. In the combined analysis, Lst-GAPDH, Lst-EFI $\alpha$, and Lst-UBI were the most stable

264 genes according to all algorithms. Thus, for future experiments using either whole animals or 
265 tissues or tissue combinations not included in our analysis, we recommend these 3 genes as the

266 first candidates for validation as reference genes.

267

268 Previous measurements of RT-qPCR reference gene stability has revealed some consistent

269 patterns across the molluscs. EF $1 \alpha$ appears to be the most effective reference gene in several

270 mollusc species in addition to the CNS and penis of L. stagnalis (Table 3). In one study of $L$.

271 stagnalis, EFl $\alpha$ was identified to remain stable in the CNS under heat stress (Foster, Lukowiak

272 \& Henry, 2015). Given that EFl $\alpha$ has also been identified to be highly stable in several other

273 molluscs, it appears to be a strong candidate reference gene across the phylum (Morga et al.,

274 2010; Wan et al., 2011; Cubero-Leon et al., 2012; Mauriz et al., 2012; Moreira et al., 2014;

275 García-Fernández et al., 2016; Huan, Wang \& Liu, 2016). An analysis of reference genes in the

276 freshwater snail Bellamya aeruginosa showed that EFI $\alpha$ and GAPDH were stable in the

277 tentacles and penis but more variable in the foot (Liu et al., 2015), similar to our findings (albeit

278 with some discrepancies of rankings in the tentacles and foot). GAPDH has also been shown to

279 be a stable reference gene in bivalves (Morga et al., 2010; Martínez-Escauriaza et al., 2018) but

280 was reported as unsuitable in abalone and octopus (Wan et al., 2011; García-Fernández et al.,

281 2016). Thus, GAPDH is not consistent across the molluscs. Additionally, GAPDH is highly

282 stable in the terrestrial gastropod Cepaea nemoralis within a given season, but expression levels

283 in this species are subject to great variation between seasons (Affenzeller, Cerveau \& Jackson,

284 2018). In our data, $L s t-U B I$ had a very consistent expression profile between tissues compared to

285 other reference genes and was found to be highly stable in the foot, mantle, and tentacles as well

286 as in the combined analysis. UBI has also shown promise in other molluscs (Sirakov et al., 2009;

287 García-Fernández et al., 2016; Affenzeller, Cerveau \& Jackson, 2018). Alpha-tubulin (TUBA) 
288 has generally produced positive results as a reference gene in several molluscan species (Sirakov 289 et al., 2009; Cubero-Leon et al., 2012; Moreira et al., 2014). However, TUBA was unstable in $C$. 290 nemoralis (Affenzeller, Cerveau \& Jackson, 2018) and we also found Lst-TUBB to be highly

291 unstable. $A C T B$ has generally produced negative results as a candidate reference gene in 292 molluscs (Cubero-Leon et al., 2012; Moreira et al., 2014; Liu et al., 2015; García-Fernández et

293 al., 2016; Huan, Wang \& Liu, 2016) and the results here from L. stagnalis are largely congruent 294 with these previous findings, although $L s t-A C T B$ was stable specifically in the foot. Finally, 295 Rapacl and $V G K C$ were identified as suitable reference genes in C. nemoralis (Affenzeller, 296 Cerveau \& Jackson, 2018). These genes did show relative stability in our analyses of the mantle 297 and lips, but were relatively unstable in the other tissues examined.

298

299

300

301

302

303

304

305

306

307 308 309 310

\section{Insert Table 3 here}

Despite the heterogeneity in top-ranked reference genes among the tissues, there was some consistency in expression stability across all tissues. Though Lst-EF1 1 , Lst-GAPDH, and Lst$U B I$ were not the top ranked in every tissue as judged by RefFinder, they were relatively stable in all tissues tested which is reflected in the stability values provided by geNorm. Thus, we recommend these genes for use in multi-tissue comparisons in L. stagnalis. In particular, LstEFI $\alpha$ and $L s t-G A P D H$ are a favourable pair as they have the most similar Cq ranges.

Importantly, despite the demonstrated stability of these genes under baseline conditions reported here, it would be crucial to directly verify their stability under any experimental conditions (Kozera \& Rapacz, 2013).

Peer] reviewing PDF | (2019:04:36960:3:0:NEW 9 Sep 2019) 


\section{Conclusion}

312 The validation of stable reference genes is necessary for the acquisition of reliable gene

313 expression data. Therefore, it is important to perform a species-specific verification of reference

314 gene stability before undertaking RT-qPCR experiments. The variable expression of the seven

315 genes among the six tissue types we investigated in L. stagnalis demonstrates that it is critical to

316 select reference genes based on the tissues of interest. The results presented here should guide

317 the selection of reference genes for tissue-specific RT-qPCR and thereby assist with future

318 studies of gene expression in the snails.

319

320 Acknowledgements

321 We thank Dr. Scott Cummins for advice, the animal care staff at St. Francis Xavier University

322 for maintaining the Lymnaea stagnalis colony, and both Hisayo Sadamoto and anonymous

323 reviewer for constructive comments.

325 References

326 Abe M, Kuroda R. 2019. The development of CRISPR for a mollusc establishes the formin Lsdial as the long-sought gene for snail dextral/sinistral coiling. Development 146:dev175976. DOI: 10.1242/dev.175976.

Affenzeller S, Cerveau N, Jackson DJ. 2018. Identification and validation of reference genes for qPCR in the terrestrial gastropod Cepaea nemoralis. PLOS ONE 13:e0201396. DOI: 10.1371/journal.pone.0201396. 
332 Aleksic M, Feng Z-P. 2012. Identification of the role of C/EBP in neurite regeneration

333 following microarray analysis of a L. stagnalis CNS injury model. BMC Neuroscience 13:2. DOI: $10.1186 / 1471-2202-13-2$.

335

336

337

338

339

340

341

342

343

344

345

346

347

348

349

350

351

352

353

354

Andersen CL, Jensen JL, Ørntoft TF. 2004. Normalization of real-time quantitative reverse transcription-PCR data: A model-based variance estimation approach to identify genes suited for normalization, applied to bladder and colon cancer data sets. Cancer Research 64:5245-5250. DOI: 10.1158/0008-5472.CAN-04-0496.

Barber RD, Harmer DW, Coleman RA, Clark BJ. 2005. GAPDH as a housekeeping gene: analysis of GAPDH mRNA expression in a panel of 72 human tissues. Physiological Genomics 21:389-395. DOI: 10.1152/physiolgenomics.00025.2005.

Bavan S, Straub VA, Webb TE, Ennion SJ. 2012. Cloning and characterization of a P2X receptor expressed in the central nervous system of Lymnaea stagnalis. PLOS ONE 7:e50487. DOI: 10.1371/journal.pone.0050487.

Benatti C, Colliva C, Blom JY, Ottaviani E, Tascedda F. 2017. Transcriptional effect of serotonin in the ganglia of Lymnaea stagnalis. Invertebrate Survival Journal 14:251-258.

Benjamin P. 2008. Lymnaea. Scholarpedia 3:4124. DOI: 10.4249/scholarpedia.4124.

Boer HH, Montagne-Wajer C, van Minnen J, Ramkema M, de Boer P. 1992. Functional morphology of the neuroendocrine sodium influx-stimulating peptide system of the pond snail, Lymnaea stagnalis, studied by in situ hybridization and immunocytochemistry. Cell and Tissue Research 268:559-566. DOI: 10.1007/BF00319163.

Boer HH, Witteveen J. 1980. Ultrastructural localization of carbonic anhydrase in tissues involved in shell formation and ionic regulation in the pond snail Lymnaea stagnalis. Cell and Tissue Research 209:383-390. DOI: 10.1007/BF00234753. 
355

356

357

358

359

360

361

362

363

364

365

366

367

368

369

370

371

372

373

374

375

Bustin SA, Benes V, Garson JA, Hellemans J, Huggett J, Kubista M, Mueller R, Nolan T, Pfaffl MW, Shipley GL, Vandesompele J, Wittwer CT. 2009. The MIQE guidelines: Minimum Information for Publication of Quantitative real-time PCR Experiments. Clinical Chemistry 55:611-622. DOI: 10.1373/clinchem.2008.112797.

Carter CJ, Rand C, Mohammad I, Lepp A, Vesprini N, Wiebe O, Carlone R, Spencer GE. 2015. Expression of a retinoic acid receptor (RAR)-like protein in the embryonic and adult nervous system of a protostome species. Journal of Experimental Zoology. Part B, Molecular and Developmental Evolution 324:51-67. DOI: 10.1002/jez.b.22604.

Chase R. 2002. Behavior and its neural control in gastropod molluscs. Oxford University Press.

Croll RP, Minnen JV. 1992. Distribution of the peptide Ala-Pro-Gly-Trp-NH2 (APGWamide) in the nervous system and periphery of the snail Lymnaea stagnalis as revealed by immunocytochemistry and in situ hybridization. Journal of Comparative Neurology 324:567-574. DOI: 10.1002/cne.903240409.

Cubero-Leon E, Ciocan CM, Minier C, Rotchell JM. 2012. Reference gene selection for qPCR in mussel, Mytilus edulis, during gametogenesis and exogenous estrogen exposure. Environmental Science and Pollution Research 19:2728-2733. DOI: 10.1007/s11356012-0772-9.

Davison A, McDowell GS, Holden JM, Johnson HF, Koutsovoulos GD, Liu MM, Hulpiau P, Van Roy F, Wade CM, Banerjee R, Yang F, Chiba S, Davey JW, Jackson DJ, Levin M, Blaxter ML. 2016. Formin is associated with left-right asymmetry in the pond snail and the frog. Current Biology 26:654-660. DOI: 10.1016/j.cub.2015.12.071.

Peer) reviewing PDF | (2019:04:36960:3:0:NEW 9 Sep 2019) 
376 Dheda K, Huggett JF, Bustin SA, Johnson MA, Rook G, Zumla A. 2004. Validation of

377

378

379

380

381

382

383

384

385

386

387

388

389

390

391

392

393

394

395

396

397

housekeeping genes for normalizing RNA expression in real-time PCR. BioTechniques 37:112-119. DOI: 10.2144/04371RR03.

Dirks RW, Raap AK, Van Minnen J, Vreugdenhil E, Smit AB, Van der Ploeg M. 1989. Detection of mRNA molecules coding for neuropeptide hormones of the pond snail Lymnaea stagnalis by radioactive and non-radioactive in situ hybridization: a model study for mRNA detection. Journal of Histochemistry \& Cytochemistry 37:7-14. DOI: 10.1177/37.1.2642295.

Dong N, Senzel A, Li K, Lu TZ, Guo C-H, Aleksic M, Feng Z-P. 2018. MEN1 tumor suppressor gene is required for long-term memory formation in an aversive operant conditioning model of Lymnaea stagnalis. Neuroscience 379:22-31. DOI: 10.1016/j.neuroscience.2018.02.018.

Ebanks SC, O’Donnell MJ, Grosell M. 2010. Characterization of mechanisms for Ca2+ and HCO3-/CO32- acquisition for shell formation in embryos of the freshwater common pond snail Lymnaea stagnalis. Journal of Experimental Biology 213:4092-4098. DOI: 10.1242/jeb.045088.

Eissa N, Hussein H, Wang H, Rabbi MF, Bernstein CN, Ghia J-E. 2016. Stability of reference genes for messenger RNA quantification by real-time PCR in mouse dextran sodium sulfate experimental colitis. PLOS ONE 11:e0156289. DOI: 10.1371/journal.pone.0156289.

Elliott CJH, Susswein AJ. 2002. Comparative neuroethology of feeding control in molluscs. The Journal of Experimental Biology 205:877-896. 
398 Feng Z-P, Zhang Z, van Kesteren RE, Straub VA, van Nierop P, Jin K, Nejatbakhsh N, Goldberg JI, Spencer GE, Yeoman MS, Wildering W, Coorssen JR, Croll RP, Buck

Foster NL, Lukowiak K, Henry TB. 2015. Time-related expression profiles for heat shock protein gene transcripts (HSP40, HSP70) in the central nervous system of Lymnaea stagnalis exposed to thermal stress. Communicative \& Integrative Biology 8. DOI:

10.1080/19420889.2015.1040954.

García-Fernández P, Castellanos-Martínez S, Iglesias J, Otero JJ, Gestal C. 2016. Selection of reliable reference genes for RT-qPCR studies in Octopus vulgaris paralarvae during development and immune-stimulation. Journal of Invertebrate Pathology 138:57-62. DOI: $10.1016 /$ j.jip.2016.06.003.

Getz AM, Wijdenes P, Riaz S, Syed NI. 2018. Uncovering the cellular and molecular mechanisms of synapse formation and functional specificity using central neurons of Lymnaea stagnalis. ACS Chemical Neuroscience 9:1928-1938. DOI: 10.1021/acschemneuro.7b00448.

Gust M, Fortier M, Garric J, Fournier M, Gagné F. 2013a. Immunotoxicity of surface waters contaminated by municipal effluents to the snail Lymnaea stagnalis. Aquatic Toxicology 126:393-403. DOI: 10.1016/j.aquatox.2012.09.001. 
421 Gust M, Fortier M, Garric J, Fournier M, Gagné F. 2013b. Effects of short-term exposure to

422

423

424

425

426

427

428

429

430

431

432

433

434

435

436

437

438

439

440

441

442

443

environmentally relevant concentrations of different pharmaceutical mixtures on the immune response of the pond snail Lymnaea stagnalis. The Science of the Total Environment 446:210-218. DOI: 10.1016/j.scitotenv.2012.12.057.

Hatakeyama D, Okuta A, Otsuka E, Lukowiak K, Ito E. 2013. Consolidation of long-term memory by insulin in Lymnaea is not brought about by changing the number of insulin receptors. Communicative \& Integrative Biology 6:e23955. DOI: 10.4161/cib.23955.

Herlitze I, Marie B, Marin F, Jackson DJ. 2018. Molecular modularity and asymmetry of the molluscan mantle revealed by a gene expression atlas. GigaScience 7. DOI: 10.1093/gigascience/giy056.

Hohagen J, Jackson DJ. 2013. An ancient process in a modern mollusc: early development of the shell in Lymnaea stagnalis. BMC Developmental Biology 13:27. DOI: 10.1186/1471213X-13-27.

Huan P, Wang H, Liu B. 2016. Assessment of housekeeping genes as internal references in quantitative expression analysis during early development of oyster. Genes \& Genetic Systems 91:257-265. DOI: 10.1266/ggs.16-00007.

Jackson DJ, Herlitze I, Hohagen J. 2016. A whole mount in situ hybridization method for the gastropod mollusc Lymnaea stagnalis. Journal of Visualized Experiments. DOI: $10.3791 / 53968$

Jonge HJM de, Fehrmann RSN, Bont ESJM de, Hofstra RMW, Gerbens F, Kamps WA, Vries EGE de, Zee AGJ van der, Meerman GJ te, Elst A ter. 2007. Evidence based selection of housekeeping genes. PLOS ONE 2:e898. DOI:

10.1371/journal.pone.0000898.

Peer) reviewing PDF | (2019:04:36960:3:0:NEW 9 Sep 2019) 
444 van der Knaap WPW, Adema CM, Sminia T. 1993. Invertebrate blood cells: Morphological

445

446

447

448

449

450

451

452

453

454

455

456

457

458

459

460

461

462

463

464

and functional aspects of the haemocytes in the pond snail Lymnaea stagnalis.

Comparative Haematology International 3:20-26. DOI: 10.1007/BF00394923.

Koene JM. 2010. Neuro-endocrine control of reproduction in hermaphroditic freshwater snails: Mechanisms and evolution. Frontiers in Behavioral Neuroscience 4. DOI: 10.3389/fnbeh.2010.00167.

Korneev SA, Kemenes I, Bettini NL, Kemenes G, Staras K, Benjamin PR, O'Shea M. 2013. Axonal trafficking of an antisense RNA transcribed from a pseudogene is regulated by classical conditioning. Scientific Reports 3:1027. DOI: 10.1038/srep01027.

Korneev SA, Vavoulis DV, Naskar S, Dyakonova VE, Kemenes I, Kemenes G. 2018. A CREB2-targeting microRNA is required for long-term memory after single-trial learning. Scientific Reports 8:3950. DOI: 10.1038/s41598-018-22278-w.

Kozera B, Rapacz M. 2013. Reference genes in real-time PCR. Journal of Applied Genetics 54:391-406. DOI: 10.1007/s13353-013-0173-x.

Liu L-L, Zhao H, Ma T-F, Ge F, Chen C-S, Zhang Y-P. 2015. Identification of valid reference genes for the normalization of RT-qPCR expression studies in human breast cancer cell lines treated with and without transient transfection. PLOS ONE 10:e 0117058. DOI: 10.1371/journal.pone.0117058.

Lukowiak K. 2016. Stress, memory, forgetting and what, Lymnaea can tell us about a stressful world. In: Physiology of Molluscs Volume 2: A Collection of Selected Reviews. Apple Academic Press and CRC Press, 68-97.

Peer] reviewing PDF | (2019:04:36960:3:0:NEW 9 Sep 2019) 
465 Lukowiak K, Haque Z, Spencer G, Varshay N, Sangha S, Syed N. 2003. Long-term memory

466 survives nerve injury and the subsequent regeneration process. Learning \& Memory

467 10:44-54. DOI: $10.1101 / 1 \mathrm{~m} .48703$.

468 Martínez-Escauriaza R, Lozano V, Pérez-Parallé ML, Pazos AJ, Sánchez JL. 2018.

469 Validation of reference genes in mussel Mytilus galloprovincialis tissues under the

$470 \quad$ presence of okadaic acid. Journal of Shellfish Research 37:93-102. DOI:

$471 \quad 10.2983 / 035.037 .0108$.

472 Mauriz O, Maneiro V, Pérez-Parallé ML, Sánchez JL, Pazos AJ. 2012. Selection of

473 reference genes for quantitative RT-PCR studies on the gonad of the bivalve mollusc

474 Pecten maximus L. Aquaculture 371:158-165. DOI: 10.1016/j.aquaculture.2012.10.020.

475 Moreira R, Pereiro P, Costa MM, Figueras A, Novoa B. 2014. Evaluation of reference genes

476 of Mytilus galloprovincialis and Ruditapes philippinarum infected with three bacteria

477 strains for gene expression analysis. Aquatic Living Resources 27:147-152. DOI:

$478 \quad 10.1051 / \mathrm{alr} / 2014015$.

479 Morga B, Arzul I, Faury N, Renault T. 2010. Identification of genes from flat oyster Ostrea

480 edulis as suitable housekeeping genes for quantitative real time PCR. Fish \& Shellfish

481 Immunology 29:937-945. DOI: 10.1016/j.fsi.2010.07.028.

482 Pfaffl MW, Tichopad A, Prgomet C, Neuvians TP. 2004. Determination of stable

483 housekeeping genes, differentially regulated target genes and sample integrity:

484 BestKeeper - Excel-based tool using pair-wise correlations. Biotechnology Letters

485 26:509-515. DOI: 10.1023/B:BILE.0000019559.84305.47.

486 Pirger Z, Laszlo Z, Hiripi L, Hernadi L, Toth G, Lubics A, Reglodi D, Kemenes G, Mark

487 L. 2010. Pituitary adenylate cyclase activating polypeptide (PACAP) and its receptors are 
present and biochemically active in the central nervous system of the pond snail Lymnaea stagnalis. Journal of Molecular Neuroscience 42:464-471. DOI: 10.1007/s12031-0109361-x.

491

492

493

Ruijter JM, Ramakers C, Hoogaars WMH, Karlen Y, Bakker O, van den Hoff MJB, Moorman AFM. 2009. Amplification efficiency: linking baseline and bias in the analysis of quantitative PCR data. Nucleic Acids Research 37:e45. DOI: 10.1093/nar/gkp045.

\section{Sadamoto H, Sato H, Kobayashi S, Murakami J, Aonuma H, Ando H, Fujito Y, Hamano} K, Awaji M, Lukowiak K, Urano A, Ito E. 2004. CREB in the pond snail Lymnaea stagnalis: cloning, gene expression, and function in identifiable neurons of the central nervous system. Journal of Neurobiology 58:455-466. DOI: 10.1002/neu.10296.

Sadamoto H, Kitahashi T, Fujito Y, Ito E. 2010. Learning-dependent gene expression of CREB1 isoforms in the molluscan brain. Frontiers in Behavioral Neuroscience 4. DOI: 10.3389/fnbeh.2010.00025.

Schmittgen TD, Livak KJ. 2008. Analyzing real-time PCR data by the comparative C(T) method. Nature Protocols 3:1101-1108.

Senatore A, Spafford JD. 2012. Gene transcription and splicing of T-Type channels are evolutionarily-conserved strategies for regulating channel expression and gating. PLOS ONE 7:e37409. DOI: 10.1371/journal.pone.0037409.

\section{Shimizu K, Iijima M, Setiamarga DH, Sarashina I, Kudoh T, Asami T, Gittenberger E,} Endo K. 2013. Left-right asymmetric expression of dpp in the mantle of gastropods correlates with asymmetric shell coiling. EvoDevo 4:15. DOI: 10.1186/2041-9139-4-15. 
510 Sirakov M, Zarrella I, Borra M, Rizzo F, Biffali E, Arnone MI, Fiorito G. 2009. Selection

511 and validation of a set of reliable reference genes for quantitative RT-PCR studies in the

512 brain of the cephalopod mollusc Octopus vulgaris. BMC Molecular Biology 10:70. DOI:

$513 \quad 10.1186 / 1471-2199-10-70$.

514 Tong Z, Gao Z, Wang F, Zhou J, Zhang Z. 2009. Selection of reliable reference genes for

515 gene expression studies in peach using real-time PCR. BMC Molecular Biology 10:71. DOI: $10.1186 / 1471-2199-10-71$.

Vandesompele J, De Preter K, Pattyn F, Poppe B, Van Roy N, De Paepe A, Speleman F. 2002. Accurate normalization of real-time quantitative RT-PCR data by geometric averaging of multiple internal control genes. Genome Biology 3:RESEARCH0034.

Wan Q, Whang I, Choi CY, Lee J-S, Lee J. 2011. Validation of housekeeping genes as internal controls for studying biomarkers of endocrine-disrupting chemicals in disk abalone by real-time PCR. Comparative Biochemistry and Physiology - Part C: Toxicology \& Pharmacology. 153:259-268. DOI: 10.1016/j.cbpc.2010.11.009.

Wyeth RC, Croll RP, Willows AOD, Spencer AN. 2009. 1-Phenoxy-2-propanol is a useful anaesthetic for gastropods used in neurophysiology. Journal of Neuroscience Methods 176:121-128. DOI: 10.1016/j.jneumeth.2008.08.028.

Xie F, Xiao P, Chen D, Xu L, Zhang B. 2012. miRDeepFinder: a miRNA analysis tool for deep sequencing of plant small RNAs. Plant Molecular Biology. DOI: 10.1007/s11103-0129885-2. 


\section{Figure 1}

Representative image of PCR products for each reference gene.

A $5 \mu \mathrm{L}$ sample of each PCR product was run on a $2 \%$ agarose gel that also contained a no primer control (NPC).

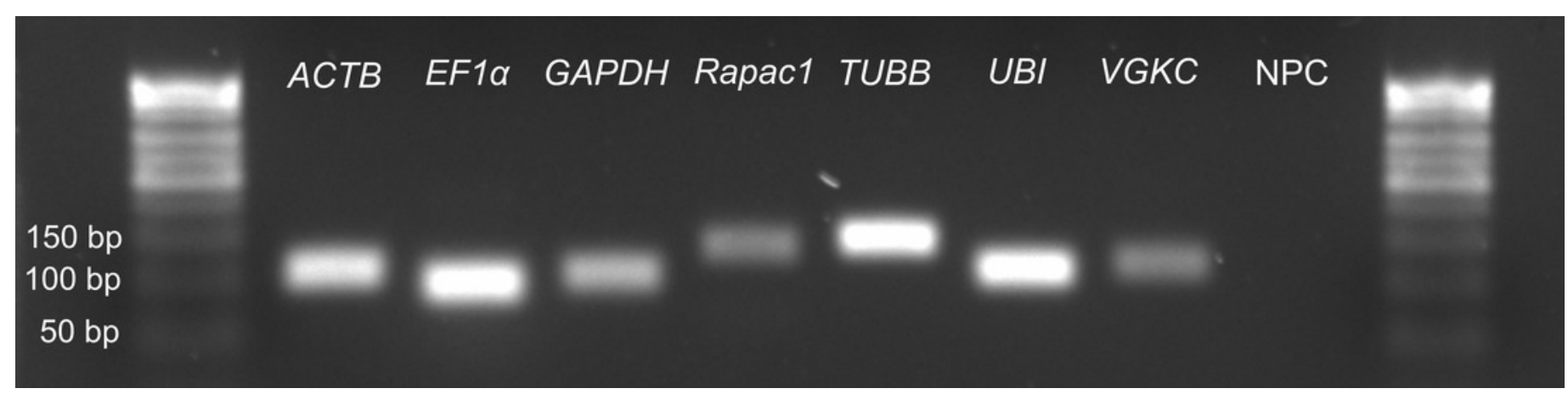


Figure 2

Expression levels for each gene in each tissue based on Cqs.

Data was collected from three replicates of $L$. stagnalis tissue and each reaction was performed in triplicate. The tissues examined were: A) CNS, B) tentacles, C) lips, D) penis, E) foot, and F) mantle. Box plot: upper and lower box limits indicate 25th and 75th percentiles, line of division in box indicates the median, and whiskers indicate the minimum/maximum values.
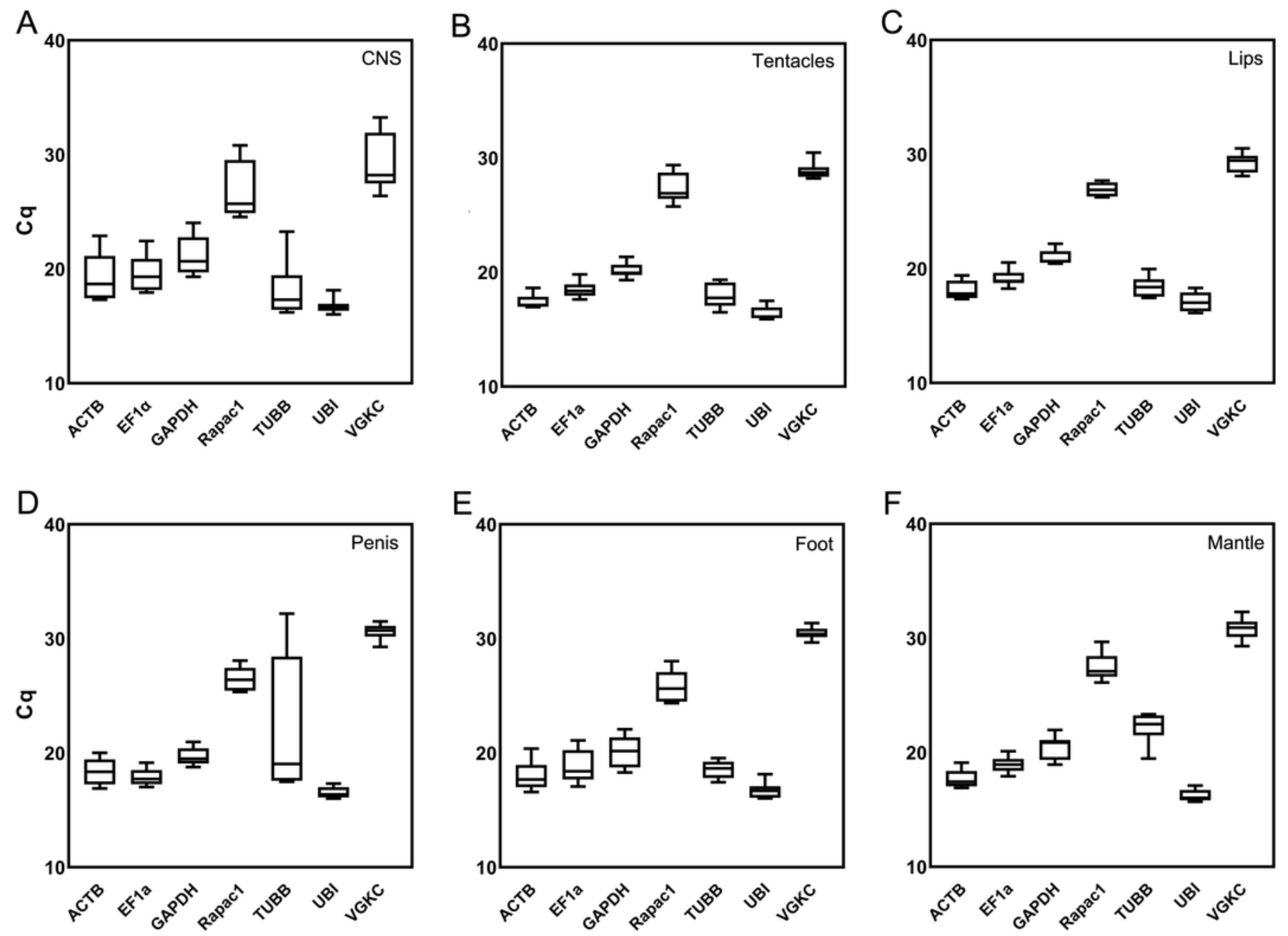


\section{Figure 3}

RefFinder rankings for all candidate reference genes by tissue.

RefFinder rankings for the A) CNS, B) tentacles, C) lips, D) penis, E) foot, and F) mantle.

RefFinder calculates rankings as the geometric mean of the rankings assigned by geNorm, NormFinder and BestKeeper. Genes are ranked in order from the least stable to the most stable in each panel. 


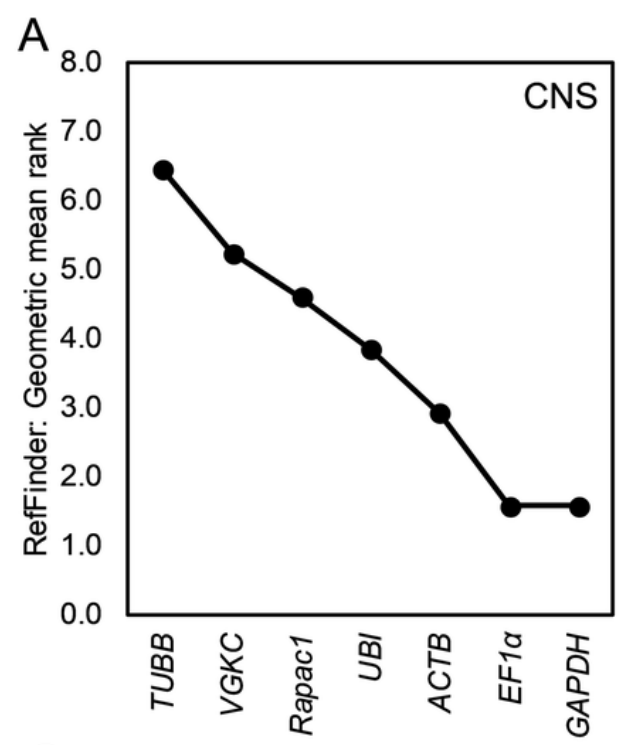

B

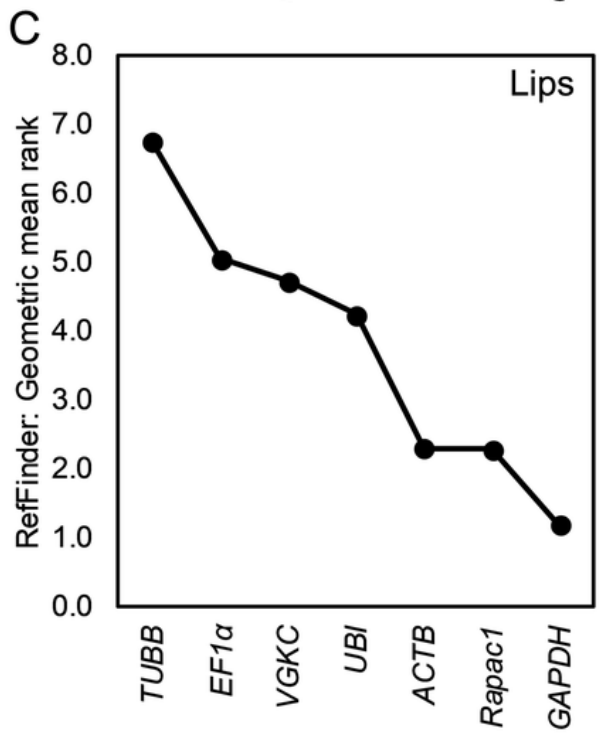

D
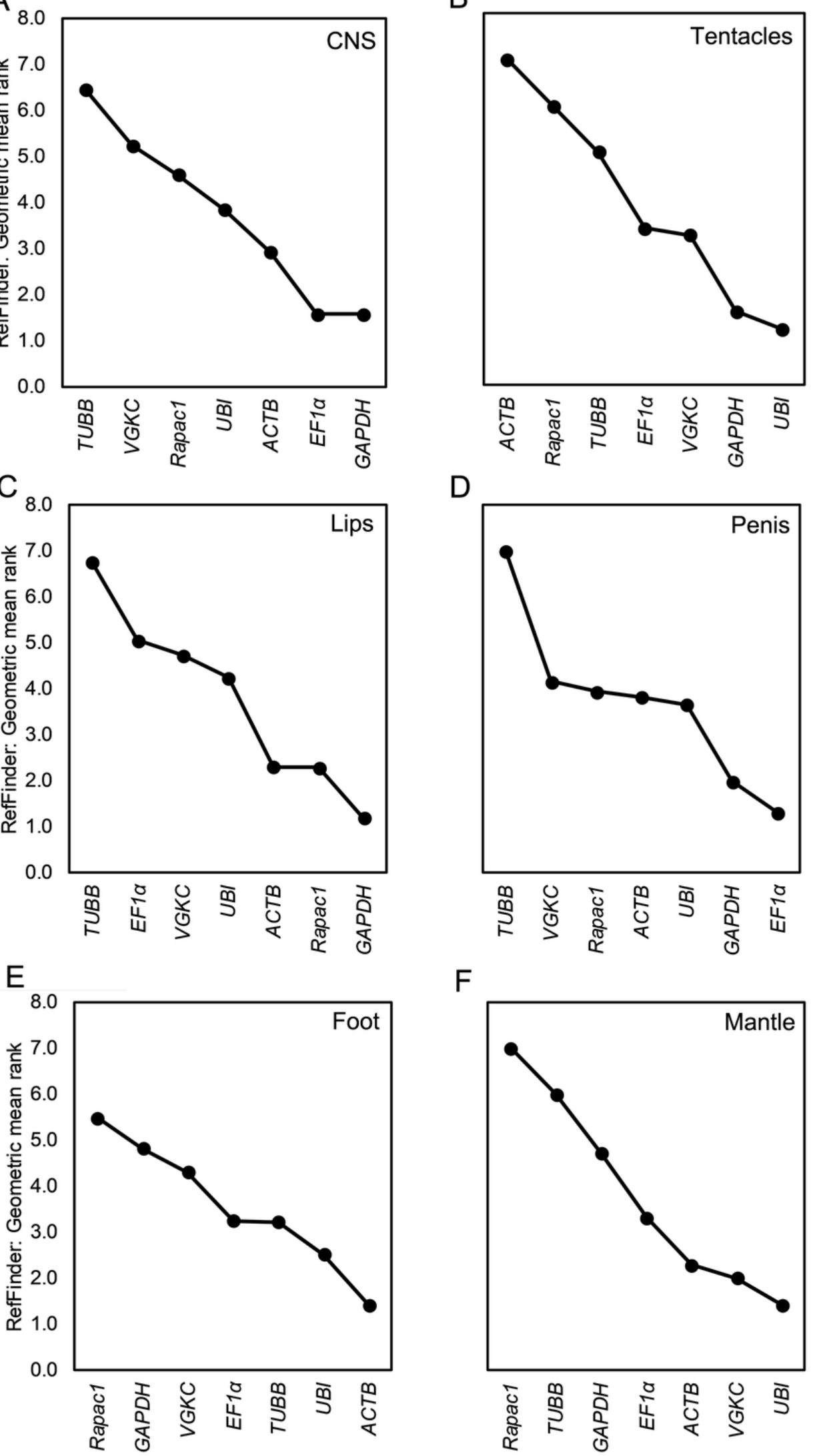

F
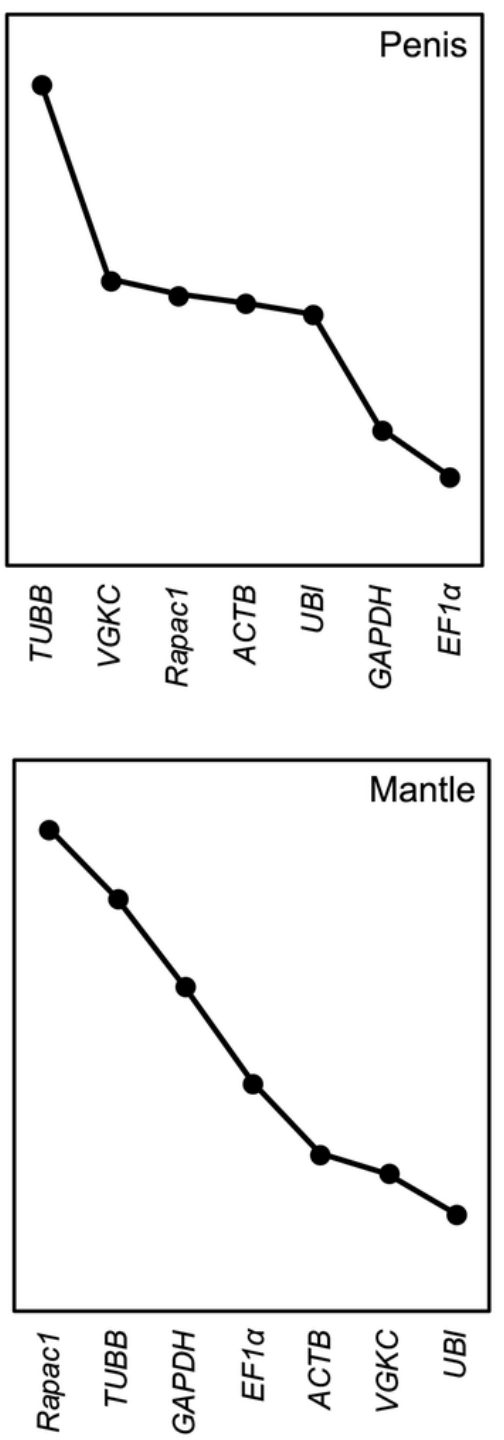

$\leftarrow$ Less stable More stable $\rightarrow$

$\longleftarrow$ Less stable More stable $\rightarrow$ 
Figure 4

Combined analysis rankings assigned to each candidate reference gene.

Data from all tissues was combined and assigned ranks by A) geNorm, B) NormFinder, C) BestKeeper and D) RefFinder. *Indicates that both genes were equally recommended. 

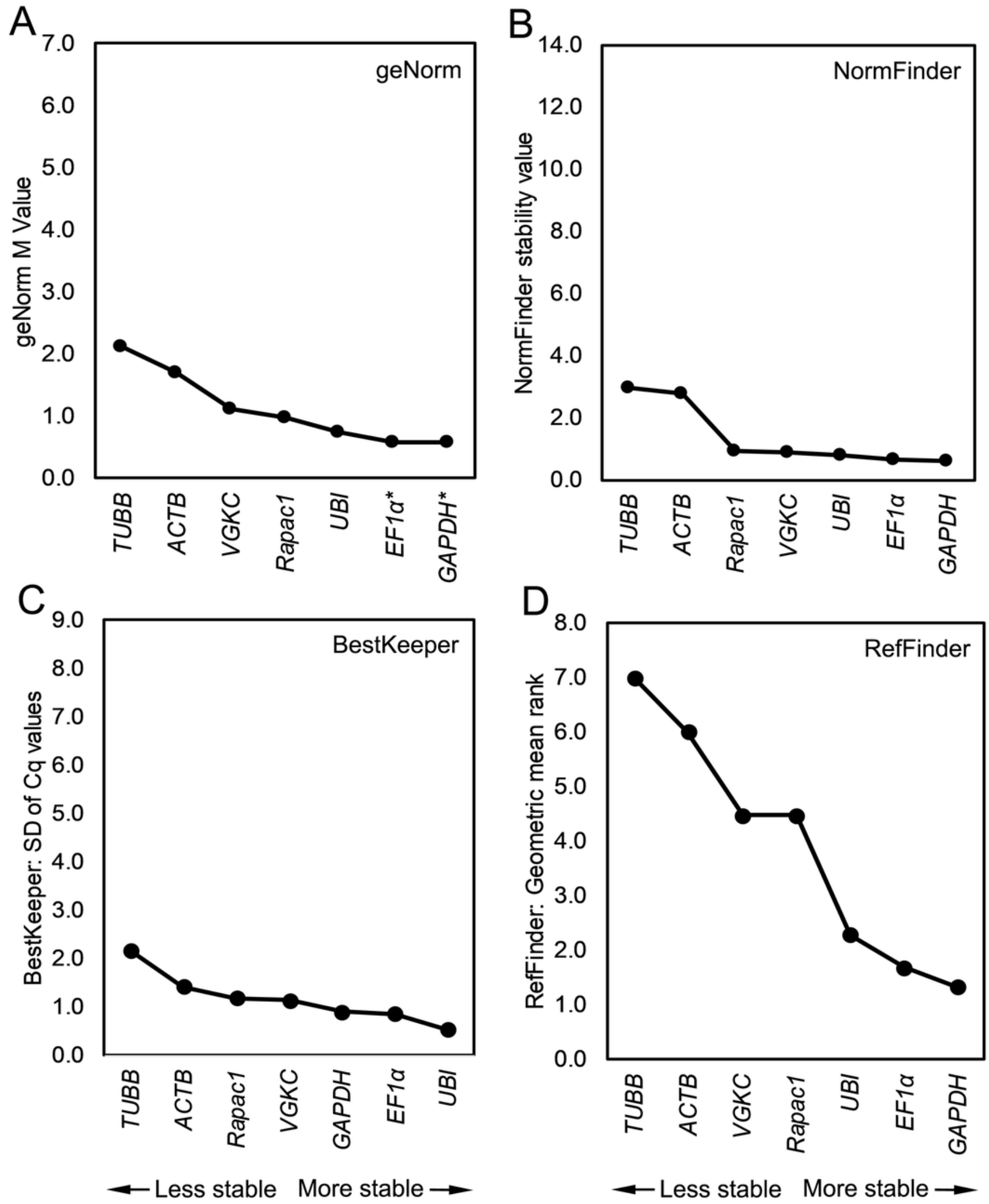


\section{Table $\mathbf{1}$ (on next page)}

Description of all primers used to amplify candidate reference genes in Lymnaea stagnalis.

Primers labeled "For" are forward primers and primers labeled "Rev" are reverse primers, all sequences are written in the 5' to $3^{\prime}$ direction. The amplification efficiency was determined from each reference gene primer set following RT-qPCR with five 1:5 serial dilutions of total RNA from $100 \mathrm{ng}$. 
Table 1. Description of all primers used to amplify candidate reference genes in Lymnaea stagnalis.

\begin{tabular}{|c|c|c|c|c|c|c|c|}
\hline Gene & Primer Sequence (5' to 3') & Function & $\begin{array}{l}\text { Product } \\
\text { Size (bp) } \\
\end{array}$ & $\begin{array}{l}\text { Tm } \\
\left({ }^{\circ} \mathbf{C}\right)\end{array}$ & Efficiency & $\mathbf{r}^{2}$ & Accession \\
\hline $\begin{array}{l}\text { Lst- } \\
\text { ACTB }\end{array}$ & $\begin{array}{l}\text { For [AGGCCAACAGAGAAAAGA] } \\
\text { Rev [AGATGCGTACAGAGAGAG] }\end{array}$ & $\begin{array}{l}\text { Cell structure and } \\
\text { motility }\end{array}$ & 97 & 56 & 2.12 & 0.999 & KX387883 \\
\hline 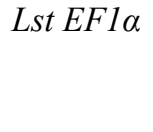 & $\begin{array}{l}\text { For [ACCACAACTGGCCACTTGATC] } \\
\text { Rev [CCATCTCTTGGGCCTCTTTCT] }\end{array}$ & $\begin{array}{l}\text { Delivery of tRNA } \\
\text { for protein } \\
\text { synthesis }\end{array}$ & 85 & 59 & 2.00 & 0.998 & MH687364 \\
\hline $\begin{array}{l}\text { Lst- } \\
\text { GAPDH }\end{array}$ & $\begin{array}{l}\text { For [CAACAACCGACAAAGCAA] } \\
\text { Rev [CATAACAAACATAGGGGCA] }\end{array}$ & $\begin{array}{l}\text { Carbohydrate } \\
\text { metabolism }\end{array}$ & 93 & 55 & 1.82 & 0.988 & MH687363 \\
\hline $\begin{array}{l}\text { Lst- } \\
\text { Rapacl }\end{array}$ & $\begin{array}{l}\text { For [GGCTCTTTCTTTCCCTTTGT] } \\
\text { Rev[TTCCTGCTCTTCTTGCGT] }\end{array}$ & $\begin{array}{l}\text { Cellular } \\
\text { trafficking }\end{array}$ & 124 & 58 & 1.82 & 0.989 & MH687365 \\
\hline $\begin{array}{l}\text { Lst- } \\
T U B B\end{array}$ & $\begin{array}{l}\text { For [GGCTAGGGGATGAAGATGA] } \\
\text { Rev [AGGATGAGGGTGAATTTGA] }\end{array}$ & $\begin{array}{l}\text { Microtubule } \\
\text { element - cell } \\
\text { structure }\end{array}$ & 130 & 56 & 1.80 & 0.993 & KX387887 \\
\hline Lst-UBI & $\begin{array}{l}\text { For [GTATTGTGGTGCTGGTGTTTT] } \\
\text { Rev[GCTTCCTCCTCTGGTTTGT] }\end{array}$ & $\begin{array}{l}\text { Regulate protein } \\
\text { function }\end{array}$ & 105 & 59 & 1.94 & 0.993 & MH687367 \\
\hline $\begin{array}{l}\text { Lst- } \\
V G K C\end{array}$ & $\begin{array}{l}\text { For [TGGCTTCCTGCTTCTCTGT] } \\
\text { Rev[GCTTCTGTCGTTGTTTTTGCT] }\end{array}$ & $\begin{array}{l}\text { Maintenance of } \\
\text { cell membrane } \\
\text { potential }\end{array}$ & 99 & 60 & 1.82 & 0.997 & MH687366 \\
\hline
\end{tabular}

Primers labeled "For" are forward primers and primers labeled "Rev" are reverse primers, all sequences are written in the 5' to 3' direction. The amplification efficiency was determined from each reference gene primer set following RT-qPCR with five 1:5 serial dilutions of total RNA from $100 \mathrm{ng}$. 


\section{Table 2 (on next page)}

Mean Cq values and standard errors of the mean (SEM) of reference genes for tissues in Lymnaea stagnalis.

Means were calculated from three replicates of $L$. stagnalis tissue, each reaction was performed in triplicate. 
1 Table 2. Mean Cq values and standard errors of the mean (SEM) of reference genes for tissues in Lymnaea stagnalis.

\begin{tabular}{|c|c|c|c|c|c|c|c|c|c|c|c|c|c|c|}
\hline \multirow[b]{2}{*}{ Tissue } & \multicolumn{2}{|c|}{ Lst- $A C T B$} & \multicolumn{2}{|c|}{ Lst-EF1a } & \multicolumn{2}{|c|}{ Lst-GAPDH } & \multicolumn{2}{|c|}{ Lst-Rapac1 } & \multicolumn{2}{|c|}{ Lst-TUBB } & \multicolumn{2}{|c|}{ Lst-UBI } & \multicolumn{2}{|c|}{ Lst-VGKC } \\
\hline & $\begin{array}{l}\mathbf{C q} \\
\text { Mean }\end{array}$ & SEM & $\begin{array}{l}\mathrm{Cq} \\
\text { Mean }\end{array}$ & SEM & $\begin{array}{l}\mathrm{Cq} \\
\text { Mean }\end{array}$ & SEM & $\begin{array}{l}\mathbf{C q} \\
\text { Mean }\end{array}$ & SEM & $\begin{array}{l}\mathbf{C q} \\
\text { Mean }\end{array}$ & SEM & $\begin{array}{l}\mathrm{Cq} \\
\text { Mean }\end{array}$ & SEM & $\begin{array}{l}\mathrm{Cq} \\
\text { Mean }\end{array}$ & SEM \\
\hline CNS & 19.27 & 0.67 & 19.49 & 0.53 & 21.10 & 0.56 & 26.81 & 0.81 & 18.30 & 0.76 & 16.72 & 0.20 & 29.27 & 0.82 \\
\hline Tentacles & 17.42 & 0.20 & 18.50 & 0.22 & 20.14 & 0.21 & 27.36 & 0.43 & 17.99 & 0.36 & 16.41 & 0.19 & 28.86 & 0.23 \\
\hline Lips & 18.19 & 0.27 & 19.14 & 0.23 & 21.01 & 0.21 & 26.97 & 0.19 & 18.39 & 0.29 & 17.11 & 0.27 & 29.26 & 0.28 \\
\hline Penis & 18.30 & 0.38 & 17.87 & 0.25 & 19.71 & 0.25 & 26.44 & 0.35 & 22.05 & 1.98 & 16.55 & 0.16 & 30.60 & 0.23 \\
\hline Foot & 18.08 & 0.41 & 18.91 & 0.48 & 20.22 & 0.46 & 25.72 & 0.46 & 18.53 & 0.25 & 16.69 & 0.24 & 30.48 & 0.17 \\
\hline Mantle & 17.67 & 0.26 & 18.91 & 0.24 & 20.41 & 0.34 & 27.57 & 0.39 & 22.16 & 0.42 & 16.24 & 0.16 & 30.78 & 0.31 \\
\hline Overall & 18.15 & 0.17 & 18.80 & 0.15 & 20.43 & 0.16 & 26.81 & 0.20 & 19.57 & 0.43 & 16.62 & 0.09 & 29.87 & 0.19 \\
\hline
\end{tabular}

2 Means were calculated from three replicates of L. stagnalis tissue, each reaction was performed in triplicate. 


\section{Table 3 (on next page)}

Summary of the stability rankings of reference genes from studies conducted in molluscs.

ARF1, adp-ribosylation factor 1; BGLU, beta-glucuronidase; COX1, cytochrome c oxidase subunit 1; CY, cyclophilin; CYP4, cytochromep450 family 4; DNARP, DNA repair protein; DRP2, DNA-directed RNA polymerase II; FIB3, fibronectin type III domain containing protein; GTP8, GTP-binding protein; $\mathrm{H} 2 \mathrm{~A}$, histone $\mathrm{H} 2 \mathrm{~A} ; \mathrm{HEL}$, RNA helicase; HNRPQ, heterogeneous nuclear ribonucleoprotein q; HPRT, hypoxanthine phosphoribosyltransferase 1; NAD4, NADH dehydrogenase subunit 4; RNAP, RNA-directed DNA polymerase; RPL5, ribosomal protein L5; RPL5, ribosomal protein L7; RPS4, 40S ribosomal protein S4; RPS27, 40S ribosomal protein S27; SDHA, succinate dehydrogenase; UBC, ubiquitin-conjugating enzyme. 
1 Table 3. Summary of the stability rankings of reference genes from studies conducted in molluscs.

\begin{tabular}{|c|c|c|c|c|}
\hline Organism & Most stable gene(s) & Least stable gene(s) & Other Genes Tested & Reference \\
\hline \multicolumn{5}{|l|}{ Gastropods } \\
\hline Haliotis discus & $E F 1 \alpha / R P L 5$ & $18 S$ rRNA & $\begin{array}{l}A C T B, B G L U, C Y, \\
G A P D H, H 2 A, \\
H P R T, S D H A, T U B B, \\
U B C, C Y P 4\end{array}$ & Wan et al. 2011 \\
\hline Bellamya aeruginosa & RPL7 & $A C T B$ & $\begin{array}{l}18 S \text { rRNA, EF } 1 \alpha, \\
G A P D H, T U B B, \\
H 2 A, D R P 2\end{array}$ & Liu et al. 2016 \\
\hline Cepaea nemoralis & $E F 1 \alpha / A C T B$ & $G A P D H$ & $\begin{array}{l}D N A R P, \text { FIB3, } \\
\text { GTP8, Rapac1, } \\
\text { RNAP, TUBA, UBI, } \\
V G K C\end{array}$ & Affenzeller et al. 2018 \\
\hline Lymnaea stagnalis & $E F 1 \alpha / G A P D H$ & $A C T B / T U B B$ & VGKC, UBI, Rapacl & Present study \\
\hline
\end{tabular}

Lymnaea stagnalis

$E F 1 \alpha / G A P D H$

TB/TUBB

$T U B A / U B I$

$18 S$ rRNA

16S rRNA, ACTB,

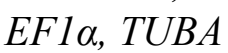

Sirakov et al. 2009

Octopus vulgaris

$B A / \cup B I$

EFI $T$ TOA 


\section{Bivalves}

Ostrea edulis

Mytilus edulis

EF $1 \alpha / 18 S$ rRNA

$A C T B$

Mytilus galloprovincialis

EFla

$A C T B$

$A C T B$

Ruditapes philippinarum

TUBA

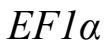

RPS18
UBI, RPL5

$28 S$ rRNA, TUBA, $H E L$

18S rRNA, TUBA Moreira et al. 2015

18S rRNA, EF 1 $\quad$ Moreira et al. 2015

$A C T B, A R F 1$, GAPDH, HNRPQ,

$U B C$
Morga et al. 2010

Cubero-Leon et al. 2012

Huan et al. 2016 


\section{Mytilus galloprovincialis GAPDH/RPS4 \\ $A C T B, C O X 1$, \\ Martínez-Escauriaza et al. 2018 GAPDH, RPS27, TIF5A}

2 ARF1, adp-ribosylation factor 1; BGLU, beta-glucuronidase; COX1, cytochrome c oxidase subunit 1; CY, cyclophilin; CYP4, cytochromep450 family 4; DNARP, DNA repair protein; DRP2, DNA-directed RNA polymerase II; FIB3, fibronectin type III domain containing protein; GTP8, GTP-binding protein; H2A, histone H2A; HEL, RNA helicase; HNRPQ, heterogeneous nuclear ribonucleoprotein q; HPRT, hypoxanthine phosphoribosyltransferase 1; NAD4, NADH dehydrogenase subunit 4; RNAP, RNAdirected DNA polymerase; RPL5, ribosomal protein L5; RPL5, ribosomal protein L7; RPS4, 40S ribosomal protein S4; RPS27, 40S ribosomal protein S27; SDHA, succinate dehydrogenase; UBC, ubiquitin-conjugating enzyme. 